\title{
Erylus aleuticus sp. nov. (Porifera: Demospongiae: Astrophorida: Geodiidae) from the Aleutian Islands, Alaska, USA
}

\author{
Helmut Lehnert $* \int$, Robert Stone ${ }^{\dagger}$ and Wolfgang Heimler ${ }^{\ddagger}$ \\ *Eichenstrasse 14, 86507 Oberottmarshausen, Germany. ${ }^{\dagger}$ Auke Bay Laboratory, National Marine Fisheries Service, \\ 11305 Glacier Highway, Juneau 99801-8626, Alaska, USA. ${ }^{\ddagger}$ Institut für Zoologie 1, Staudtstrasse 4, D-91054 Erlangen, Germany. \\ `Corresponding author, e-mail: Lehnert@spongetaxonomics.de
}

\begin{abstract}
A new species of Erylus from the Aleutian Islands is described. This is the first record of the genus from the Aleutian Islands. The new species differs from all other known species of Erylus in the presence of different types of monaxonic megascleres, ranging from oxeas, strongyles, styles, tylostyles to tylotes, often with unequal ends and irregular modifications of these types. The lack of a secondary category of asters is also unusual for the genus.
\end{abstract}

\section{INTRODUCTION}

The genus Erylus, Gray, 1867 was erected for Erylus mammilaris (Schmidt, 1862) from the Adriatic Sea. The genus is known from the Mediterranean Sea, Atlantic and Pacific Oceans and contains 57 nominal species, but the taxonomic validity of all species has been questioned (Adams \& Hooper, 2001). Some species reportedly contain bioactive compounds with antitumour, antifungal and antiviral properties, especially against retroviruses such as the human immunodeficiency virus (HIV) (Adams \& Hooper, 2001). The genus Erylus and five other genera constitute the family Geodiidae Gray, 1867 which is characterized by the presence of sterrasters as the main cortical microscleres and various forms of triaenes among the megasleres. Additional microscleres are euasters and microrhabds. Growth forms are massive or thickly encrusting. There is still some debate whether the family should be divided into two families, Erylidae and Geodiidae, or whether all genera belong to a single family with the latter view currently favoured (Uriz, 2002). The genus Erylus is characterized by short-shafted triaenes, usually flattened aspidasters and by centrotylote microrhabds. In addition to the triaenes, most species have oxeas as megascleres but, as will be shown below, other spicule types occur as well.

For a recent review of worldwide species we refer to Adams \& Hooper (2001). It is the purpose of the present publication to describe a new species of Erylus and compare it with other congeners.

\section{MATERIALS AND METHODS}

The holotype was collected during a cruise of the RV 'Velero IV' along the Aleutian Islands in June and July 2004. Samples were collected with the submersible 'Delta' and stored in 95\% ethanol after collection. Identification followed the usual procedures of obtaining sections and spicule preparations for investigation by light microscopy and scanning electron microscopy (SEM), described earlier (e.g. Lehnert \& van Soest, 1996). The SEM studies were carried out at the Institute for Zoology I in Erlangen, Germany.

\section{SYSTEMATICS}

Order: ASTROPHORIDA

Family: GEODIIDAE Gray, 1867

Genus: Erylus Gray, 1867

Erylus aleuticus sp. nov.

Material

Holotype: 6230-20-4, collected $34.8 \mathrm{~km}$ north of Amlia Island $\left(52^{\circ} 28^{\prime} 8.5^{\prime \prime} \mathrm{N} \quad 173^{\circ} 35^{\prime} 52.9^{\prime \prime} \mathrm{W}\right)$ at $190 \mathrm{~m}$ depth. Deposited at the Senckenberg Museum, Frankfurt am Main, Germany, under the registration no. SMF 10330.

\section{Description}

The holotype (Figure 1A) consists of three attached flattened lobes with oval to circular outlines; the largest lobe is $17 \times 12 \times 3.5 \mathrm{~cm}$, all three lobes are part of the same individual. The surface is creamy white and hard, due to an ectosomal crust of aspidasters about $0.5 \mathrm{~mm}$ in thickness. Numerous uniporal orifices are scattered over the surface at intervals of $0.5-2.0 \mathrm{~mm}$. They are round, $0.5-1.0 \mathrm{~mm}$ in diameter and slightly $(<0.5 \mathrm{~mm})$ raised above the surface. The choanosome is softer and choanosomal megascleres are extremely variable with many malformed and distorted spicules, irregularly bent or straight. Spicule shapes (Figure 1C,D) range from oxeas, styles, tylostyles, strongyles to tylotes, some with irregular diameters; some bat-shaped, size-range, $520-1728 \times 18-42 \mu \mathrm{m}$; orthotriaenes (Figure 1B), also with variable rays, blunt or pointed, rays of cladome often bent in one direction, rhabds, $615-790 \times 23-42 \mu \mathrm{m}$, clad, $270-380 \times 24-35 \mu \mathrm{m}$; aspidasters (Figure 2A,B), measuring 200-225 $\times 160-$ $175 \times 28-62 \mu \mathrm{m}$; dermal centrotylote microstrongyles 


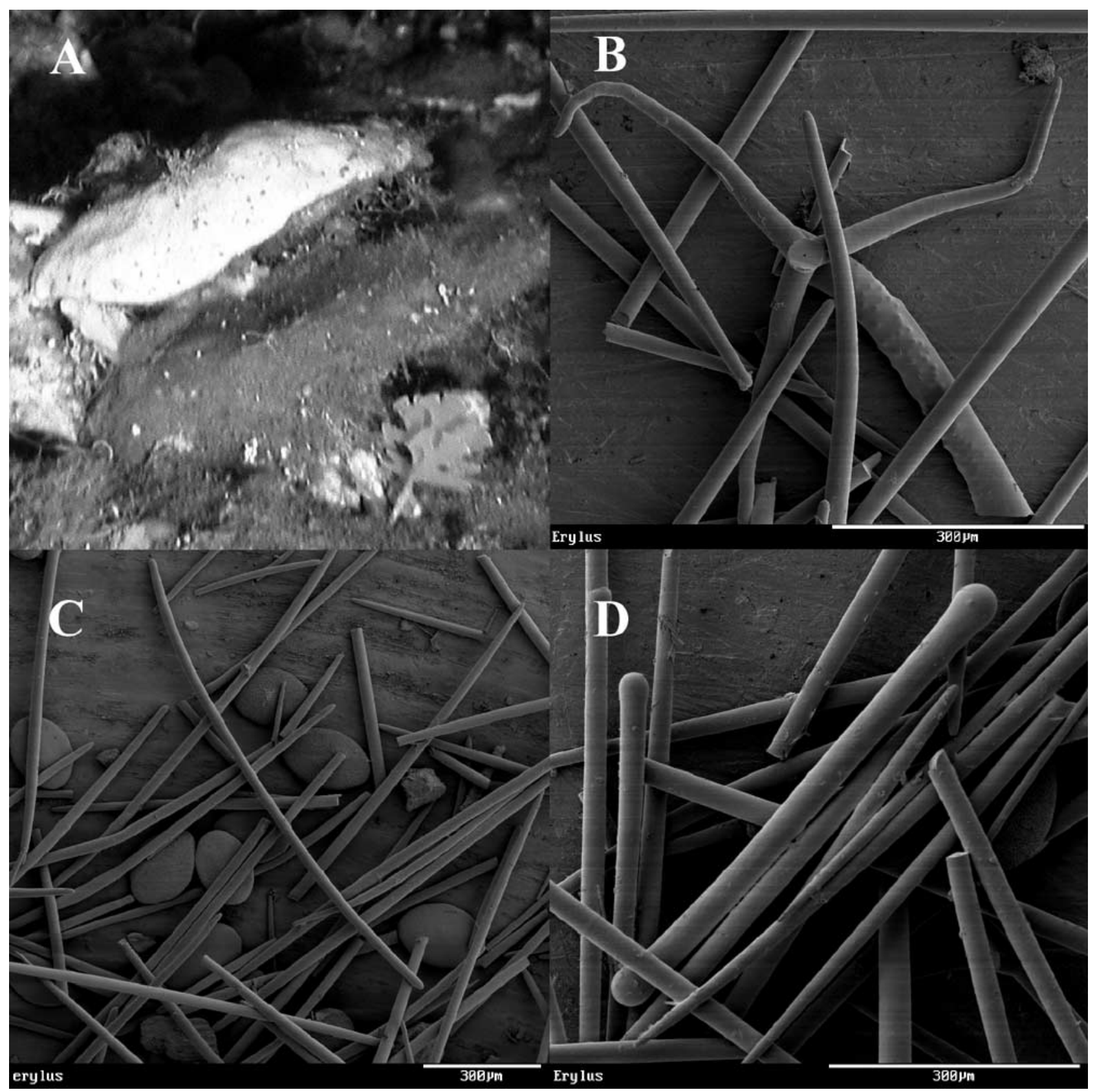

Figure 1. (A-D) Erylus aleuticus sp. nov. (A) Holotype, in situ at $190 \mathrm{~m}$ depth near Amlia Island; (B) cladome of triaene with bent rays; $(\mathrm{C})$ strongylote megasclere among other spicules; and (D) tylote.

(Figure 2C), 30-47×4-6 $4 \mathrm{~m}$; oxyasters (Figure 2D), 9$12 \mu \mathrm{m}$ in diameter.

\section{Distribution}

Known only from the type-locality.

\section{DISCUSSION}

Erylus aleuticus sp. nov. is unique with its many types of monaxonic megasleres and the lack of a large category of asters. As will be shown in more detail below, most other known species of Erylus have oxeas as choanosomal megascleres; occasionally strongyles are reported or, for some species (described by Lendenfeld, 1910, see below), a mixture of oxeas, styles and strongyles are present. For E. rotundus Lendenfeld, 1910 (briefly described below) 'aster like rhabd clusters' are reported, so several types of choanosomal megascleres and spicule 'anomalities' are not unusual in the genus. However, the high variety of monaxonic megascleres present in E. aleuticus sp. nov. has not been demonstrated for congeners. We are aware that malformed spicules occur in many species but in Erylus aleuticus they occur in unusually high quantities so that they cannot be regarded as rare exceptions only. Growth forms, spicule categories and their measurements as well as the distribution of North- and central Pacific species of Erylus are shown in Table 1.

Erylus aleuticus sp. nov. shares strongylote megascleres and aspidasters of similar size with E. cornutus Wilson, 1925: 306, but E. cornutus is lacking all other types of monaxonic megascleres and has strongylasters only, which are considerably larger. Furthermore E. cornutus is 


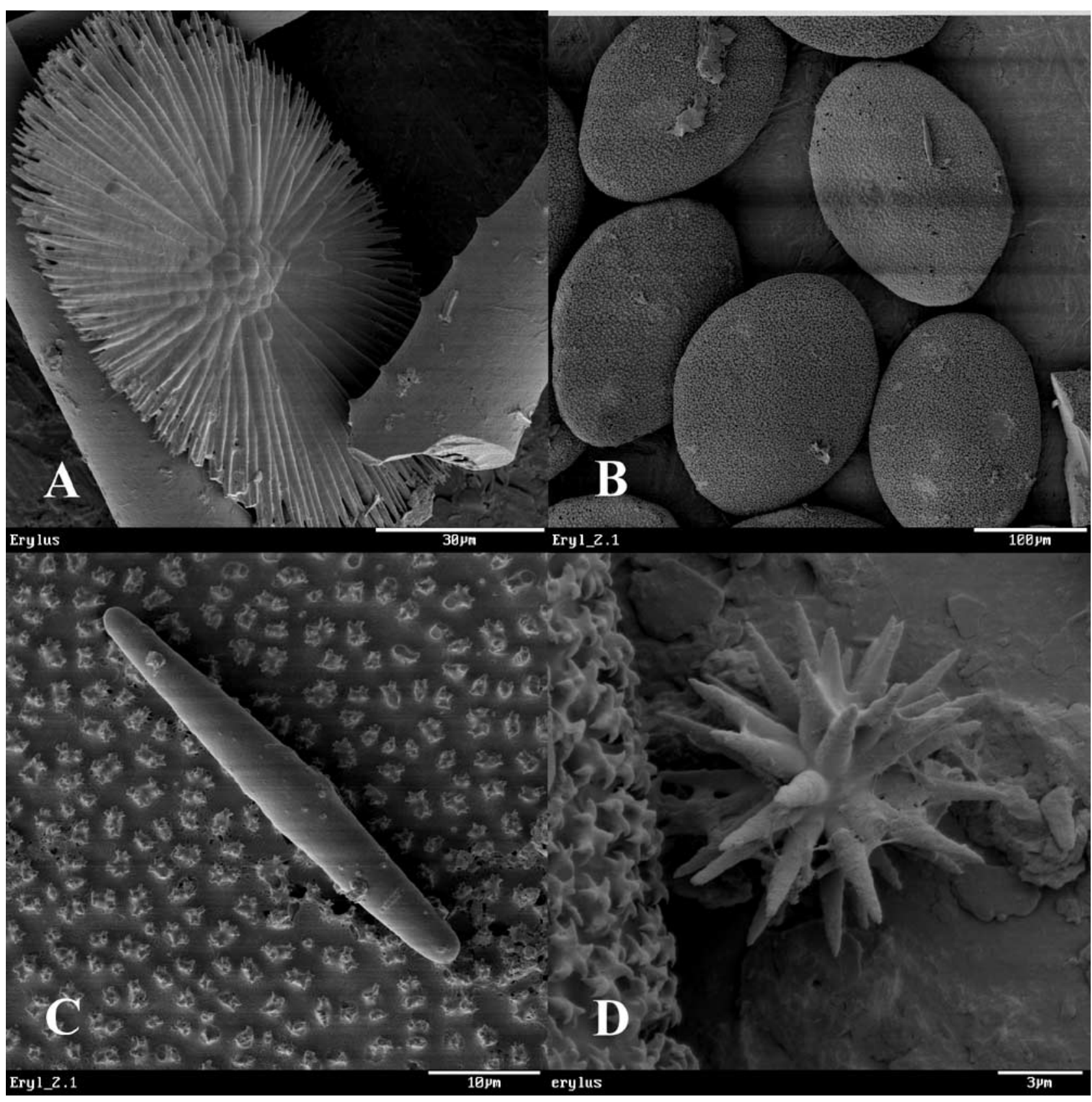

Figure 2 (A-D) Erylus aleuticus sp. nov. (A) Juvenile aspidaster; (B) aspidasters; (C) centrotylote microstrongyle on the surface of an aspidaster; and (D) oxyaster.

described from the Phillipines which makes conspecifity quite unlikely. Erylus placenta Thiele, 1898 from Japan is geographically the closest record of another congeneric species. It is described as thinly encrusting $(2-3 \mathrm{~mm}$ in thickness) and reddish-grey coloured in ethanol and so it differs in both growth form and colour. The presence of oxeas as the only megascleres and smaller aspidasters further differentiate E. aleuticus sp. nov. from E. placenta. Erylus placenta has a category of similar sized asters but they are sphaerasters and, in contrast to E. aleuticus, a large category of oxyasters is present.

Erylus schmiederi Austin, 1996: 248 was recorded from the Pacific coast of Mexico at $37 \mathrm{~m}$ depth. In addition to short-shafted orthotriaenes it also has dichotriaenes, oxeas $(740-1340 \times 19-25 \mu \mathrm{m})$, and rare styles and strongyles $(900-1550 \times 14 \mu \mathrm{m})$ as monaxonic megascleres. The aspidasters $(65-125 \times 53-73 \times 10-15 \mu \mathrm{m})$ are considerably smaller than in E. aleuticus. Centrotylote microstrongyles $(30-50 \times 1-4 \mu \mathrm{m})$ are about the same size as in many Erylus species. Oxyasters occur in two size-categories: small $(8-13 \mu \mathrm{m})$, multiple rayed with roughened apices and, larger, typically six-rayed oxyasters, typically also with roughened apices $(20-25 \mu \mathrm{m})$. Erylus aleuticus is lacking the dichotriaenes and the second category of asters of E. schmiederi while E. schmiederi is lacking the high variety of megascleres. Erylus discastera Dickinson, 1945 is known from the Gulf of California at $140 \mathrm{~m}$ depth. Dickinson (1945) described plagiotriaenes 'about $40 \mu$ by $2000 \mu$ ' which is, we assume, the dimension of the rhabd. He also mentions occasional triaenes which are almost calthrops but does not provide their sizes. Megascleres are oxeas $(20 \times 600 \mu \mathrm{m})$. Aspidasters are 


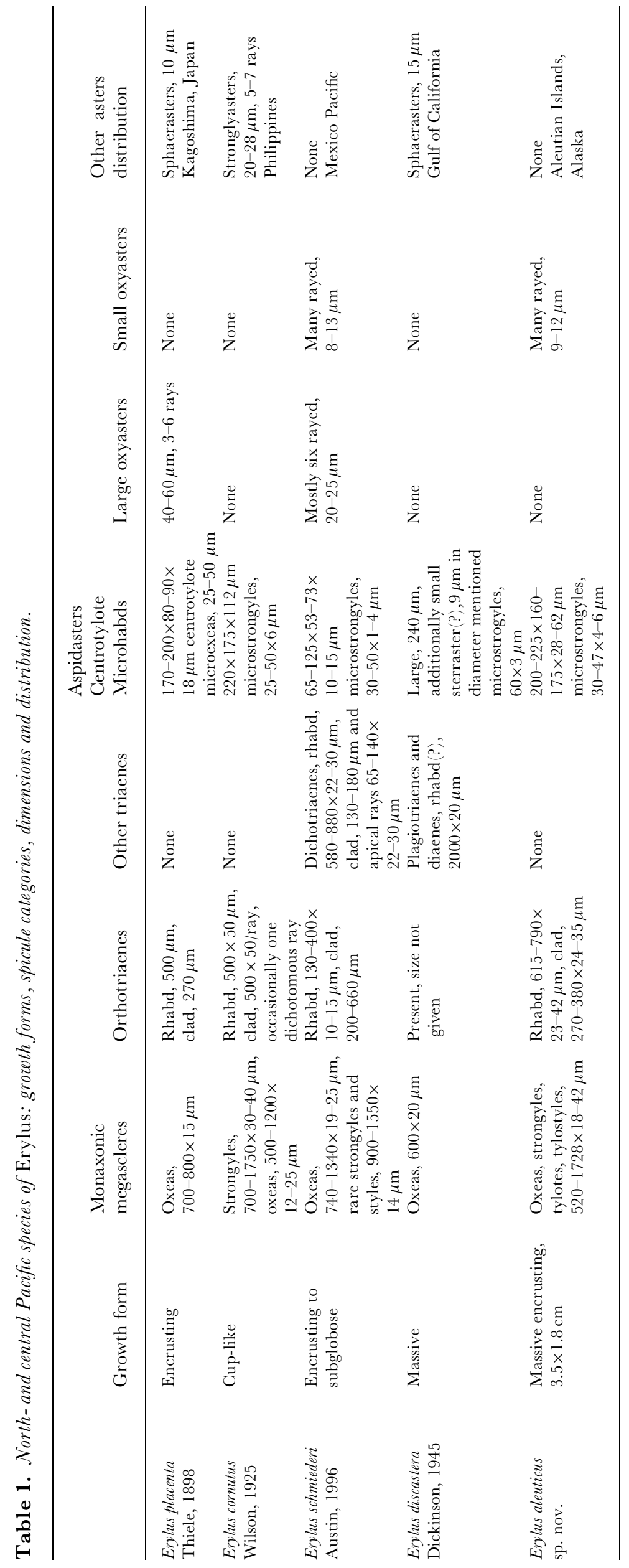


large with a maximum diameter of $240 \mu \mathrm{m}$ ('disc shaped sterrasters') and he also mentions very abundant sterrasters $(9 \mu \mathrm{m})$, spherasters $(15 \mu \mathrm{m})$ and microstrongyles $(60 \times 3 \mu \mathrm{m})$. Erylus discastera is somewhat unusual for the genus given the presence of short-shafted triaenes in addition to a second category of long triaenes and diaenes. The aspidasters are very large and one cannot be sure what is meant by the small category of sterrasters. However, the species differs from E. aleuticus by having oxeas only as monaxonic megascleres, by the possession of long-shafted triaenes, larger aspidasters, and small sterrasters (whatever they might be), and the lack of oxyasters.

There are seven additional species of Erylus known from the Pacific Ocean. All of them occur in geographically distant areas, which make conspecifity somewhat unlikely; however, we briefly discuss these here. Erylus monticularis Kirkpatrick, 1900 from Funafuti in the central Pacific is thinly encrusting, has oxeas $(210 \times 10 \mu \mathrm{m})$, small orthotriaenes, microxeas $(40-80 \mu \mathrm{m})$, oxyasters $(18-30 \mu \mathrm{m})$, tylasters $(10 \mu \mathrm{m})$ and aspidasters $(150 \times 114 \mu \mathrm{m})$. Erylus decumbens Lindgren, 1897 from Java is again an encrusting species with only oxeas $(800 \times 24 \mu \mathrm{m})$ as monaxonic megascleres. Orthoplagiotriaenes (rhabd $420 \times 28 \mu \mathrm{m}$, clad $280 \mu \mathrm{m})$, microstrongyles $(60 \times 6 \mu \mathrm{m})$, oxyasters $(24 \mu \mathrm{m})$, spherasters $(10 \mu \mathrm{m})$, aspidasters $(182 \times 120 \times$ $28 \mu \mathrm{m})$ are all present. Erylus oxyaster Lendenfeld, 1910 from the Galapagos Islands has digitate processes, oxeas $(1800-2900 \times 60-85 \mu \mathrm{m})$ and rare styles $(1900-$ $2300 \times 60-105 \mu \mathrm{m})$. Lendenfeld $\quad(1910)$ mentions additional rare 'angularly bent and branched rhabd derivatives' of the same dimensions as the oxeas. Based on the figures provided in the description they are actually fused oxeote spicules which are remarkable because of the irregular rhabd derivatives of E. aleuticus. Erylus oxyaster possesses rare plagiotriaenes (rhabd $900 \times 75-90 \mu \mathrm{m}$ ), dichotriaenes (rhabd, 600-1600 ×70-105 $\mu \mathrm{m}$ ), microstrongyles $(31-93 \times 3.5-4.5 \mu \mathrm{m})$, oxyasters $(10-90 \mu \mathrm{m})$ and aspidasters $(208-243 \times 125-150 \times 30-40 \mu \mathrm{m})$. Erylus nobilis Thiele, 1900 from Ternate in western Indonesia is cylindrical, with only oxeas $(1000 \times 30 \mu \mathrm{m})$ as monaxonic megascleres, orthotriaenes (rhabd $600 \times 40 \mu \mathrm{m}$, clad $250 \mu \mathrm{m})$, centrotylote microstrongyles $(48 \times 6 \mu \mathrm{m})$, 'acanthtylasters' $(20 \mu \mathrm{m} / \mathrm{ray})$, and aspidasters $\left(190 \times 90^{-}\right.$ $100 \times 40 \mu \mathrm{m})$. Erylus sollasi Lendenfeld, 1910 from the Hawaiian Islands is an irregularly-shaped massive species with blunt oxeas $(425-980 \times 8-24 \mu \mathrm{m})$ and rare pointed oxeas, strongyles and styles of similar dimensions, plagiotriaenes (rhabd $140-520 \times 8-22 \mu \mathrm{m}$ ) and simple or bifurcare clads $(70-300 \mu \mathrm{m})$, centrotylote microxeas $(30-78 \times 2.5-5 \mu \mathrm{m})$ and rare anisoactine, branched microxea derivatives, 'acanthtylasters' $(10-38 \mu \mathrm{m})$, and aspidasters $(95-156 \times 55-82 \times 7.4-14 \mu \mathrm{m})$. Erylus rotundus Lendenfeld, 1910 also from Hawaii is an irregular-shaped massive species with oxeas and strongyles $(310-650 \times 6-$ $15 \mu \mathrm{m}$ ) and rare styles, angularly bent and rarely branch bearing rhabd derivatives of similar dimensions. Lendenfeld (1910) also describes 'aster-like rhabd-clusters' $(125-180 \mu \mathrm{m}$ in diameter), orthoplagiotriaenes (rhabd 170-370 ×6-12 $\mathrm{m}$, clad, $80-270 \mu \mathrm{m})$, microxeas (30$98 \times 1.5-7.5 \mu \mathrm{m}), \quad$ acanthylasters $(12-31 \mu \mathrm{m})$, oxyasters
$(7-17 \mu \mathrm{m})$, and aspidasters $(50-77 \times 46-70 \times 4.4-8.8 \mu \mathrm{m})$. Erylus caliculatus Lendenfeld, 1910 from Hawaii is inverted, conical, and dirty white in spirit. It has blunt oxeas and strongyles $(410-850 \times 10-19 \mu \mathrm{m})$, orthotriaenes (rhabd 200-300 $\times 13-20 \mu \mathrm{m}$, clads $125-220 \mu \mathrm{m}$ ), centrotylote microstrongyles $(39-52 \times 3-5 \mu \mathrm{m})$, acanthylasters $(17-50 \mu \mathrm{m})$, oxyspherasters $(9-18 \mu \mathrm{m})$ and aspidasters $(72-88 \times 67-77 \times 10.6-12.8 \mu \mathrm{m})$.

This study was funded by the National Oceanic and Atmospheric Administration (Alaska Fisheries Science Center) and the North Pacific Research Board. Many thanks to the crews of the RV 'Velero IV' and Delta Oceanographics for professional and friendly support during fieldwork.

\section{REFERENCES}

Adams, G.L. \& Hooper, J.N.A., 2001. A revision of Australian Erylus (Porifera: Demospongiae: Astrophorida: Geodiidae) with a tabular review of worldwide species. Invertebrate Taxonomy, 15, 319-340.

Austin, W.C., 1996. Sponges from Rocas Alijos. In Scientific results from the Cordell expeditions (ed. R.W. Schmieder). Monographiae Biologicae V, 75, 237-256.

Dickinson, M.G., 1945. Sponges of the Gulf of California. Allan Hancock Pacific Expeditions, 11, I-IV, 1-55, pls. 1-97.

Gray, J.E., 1867. Notes on the arrangement of sponges, with descriptions of some new genera. Proceedings of the Zoological Society, London, 2, 492-558, pls. 27-28.

Kirkpatrick, R., 1900. Descriptions of sponges from Funafuti. Annals and Magazine of Natural History, 7, 345-362, pls. 13-15.

Lehnert, H. \& Soest, R.W.M. van, 1996. North Jamaican deep fore-reef sponges. Beaufortia, 46(4), 53-81.

Lendenfeld, R.L. von, 1910. The Sponges. 2. The Erylidae. In Reports on the Scientific Results of the Expedition to the Eastern Tropical Pacific, in charge of Alexander Agassiz, by the U.S. Fish Commission Steamer "Albatross", from October, 1904, to March, 1905, Lieut. Commander L.M. Garrett, U.S.N., Commanding, and of other Expeditions of the "Albatross", 1888-1904. Memoirs of the Museum of Comparative Zoology at Harvard College, 41, 261-324, pls. 1-8.

Lindgren, N.G., 1897. Beitrag zur Kenntnis der Spongienfauna des Malaiischen Archipels und der Chinesischen Meere. Zoologischer Anzeiger, 20, 480-487.

Schmidt, O., 1862. Die Spongien des adriatischen Meeres. Wilhelm Leipzig: Engelmann.

Schmidt, O., 1868. Die Spongien der Küste von Algier. Mit Nachträgen $z u$ den Spongien des Adriatischen Meeres (drittes Supplement). Leipzig: Verlag W. Engelmann.

Thiele, J., 1898. Studien über pazifische Spongien. Zoologica, 24, $1-72,8$ pls.

Thiele, J., 1900. Kieselschwämme von Ternate. I. Abhandlungen Herausgegeben von der Senckenbergischen Naturforschenden Gesellschaft, Frankfurt, 25, 19-80.

Uriz, M.J., 2002. Family Geodiidae Gray, 1867. In Systema Porifera: a guide to the classification of sponges (ed. J.N.A. Cooper and R.W.M. van Soest), pp. 134-140. New York: Kluwer Academic/Plenum Publishers.

Wilson, H.V., 1925. Silicious and horny sponges collected by the U.S. Fisheries Steamer "Albatross" during the Philippine Expedition, 1907-10. Bulletin of the United States National Museum, $100(2) 4,273-532$, pls. 37-52.

Submitted 8 November 2005. Accepted 9 April 2006. 